\title{
CIRCULATORY EFFECTS OF CHRONIC HYPERVOLEMIA IN POLYCYTHEMIA VERA*
}

\author{
By LEONARD A. COBB, ROBERT J. KRAMER ANd CLEMENT A. FINCH
}

(From the Department of Medicine, School of Medicine, University of Washington, Seattle, Wash.)

(Submitted for publication May 11, 1960 ; accepted July 21, 1960)

In this study the relationship of cardiac output to oxygen supply on the one hand and to blood volume on the other is examined in patients with polycythemia vera.

Oxygen supply is a function of the cardiac output and the oxygen content of arterial blood. There is good evidence that cardiac output may be altered by changes in either tissue oxygen requirements or oxygen content. Thus, with increased physical activity or hyperthyroidism, cardiac output is elevated. Likewise, in severe anemia or with the hypoxia of high altitude, cardiac output rises. The relationship between cardiac output and arterial oxygen content was well illustrated by Richardson and Guyton in dogs whose hematocrits were rapidly altered by blood exchange without blood volume change (1). Cardiac output fell with polycythemia and rose with anemia ; maximal oxygen delivery occurred at a normal hematocrit. From the above considerations it would seem reasonable to postulate that cardiac output is regulated in some manner by tissue oxygen requirements and blood oxygen concentration.

The influence of blood volume as a cardiac regulatory mechanism has been demonstrated in dogs as well as in man (2-6). Such observations following the acute manipulation of blood volume have shown an augmentation of cardiac output and stroke volume in hypervolemia. The effects of chronic hypervolemia in cardiovascular regulation have not been reported.

Polycythemia vera presents an interesting situation in which the above factors may be examined. There is a long-standing surplus of hemoglobin and blood oxygen without a proportionate in-

* These studies have been supported in part by grants from the United States Public Health Service (H-908-C8 and $\mathrm{H}-2994)$, the Washington State Heart Association, and State of Washington Initiative 171 Funds for Research in Biology and Medicine. crease in tissue oxygen requirements; furthermore, blood volume is increased in polycythemia vera. The increased arterial oxygen content and blood viscosity might be expected to decrease cardiac output, whereas chronic hypervolemia might have the opposite effect. Our studies were designed to evaluate these possibilities.

\section{MATERIAL AND METHODS}

Three types of subjects were selected for study. Group Ia consisted of 6 subjects with incidental illness not considered to affect erythropoiesis or cardiac function. These individuals were ambulatory and asymptomatic: they had hematocrits between 40 and 50 per cent and normal blood volumes. There was no recognizable cardiac or pulmonary disease. Electrocardiograms were all normal, and heart size by X-ray was not enlarged. Group Ib consisted of 4 subjects with hematocrits of 50 to 55 per cent and with normal or only slightly enlarged blood volumes. These subjects also had no evidence of cardiac or pulmonary disease. X-rays showed normal sized hearts and, except for isolated left axis deviation in D.G., electrocardiograms were normal.

Group II consisted of 10 patients with polycythemia vera, 5 of whom had symptoms of approximately 1 month's duration. The other 5 had been previously treated, but were all polycythemic and hypervolemic at the time of initial studies. The spleen was palpable in all subjects except S.Ta., S.Tu. and B.P. Electrocardiograms were normal, except for left ventricular hypertrophy in Patient S.Ta. and right bundle branch block in B.P. Patient A.L. had a previous history of paroxysmal auricular fibrillation. Cardiac enlargement of 25, 20 and 25 per cent was present in Patients S.Ta., G.S. and A.L., but was normal in the other subjects ( \pm 10 per cent). Pertinent clinical data on the 20 subjects studied are summarized in Tables I and II.

Single studies were performed in Groups Ia and Ib. In 7 patients with polycythemia vera, studies were repeated after phlebotomy. The patients were in the supine position when the hemodynamic measurements were made 1 to 3 hours after a light nonfat breakfast. No premedication was given. Intravascular pressures were recorded on a Sanborn polygraph using Statham P23D strain gage transducers. Heart rate was measured from the electrocardiogram obtained during the determination of cardiac output. Cardiac output was measured by the 
TABLE I

Clinical and laboratory summary of normovolemic subjects

\begin{tabular}{|c|c|c|c|c|c|c|c|}
\hline \multirow[b]{2}{*}{ Patient } & \multirow[b]{2}{*}{ Age } & \multirow[b]{2}{*}{ Sex } & \multirow[b]{2}{*}{ Weight } & \multirow{2}{*}{$\begin{array}{c}\text { Mean } \\
\text { brachial } \\
\text { arterial } \\
\text { pressure }\end{array}$} & \multirow[b]{2}{*}{$\begin{array}{c}\text { Arterial } \\
\text { hematocrit }\end{array}$} & \multicolumn{2}{|c|}{$\begin{array}{c}\text { Arterial oxygen } \\
\% \text { saturation }\end{array}$} \\
\hline & & & & & & Air & $\begin{array}{l}100 \% \\
\text { Oxygen }\end{array}$ \\
\hline Ia Norm & $\begin{array}{c}y r s \\
\text { atocri }\end{array}$ & & kg & $m m \mathrm{Hg}$ & $\%$ & & \\
\hline $\begin{array}{l}\text { A.R. } \\
\text { D.B. } \\
\text { W.S. } \\
\text { C.H. } \\
\text { Z.B. } \\
\text { O.W. }\end{array}$ & $\begin{array}{l}42 \\
49 \\
50 \\
71 \\
52 \\
42\end{array}$ & $\begin{array}{l}M \\
M \\
M \\
F \\
F \\
F\end{array}$ & $\begin{array}{l}59.5 \\
86.4 \\
82.6 \\
69.0 \\
64.8 \\
66.6\end{array}$ & $\begin{array}{r}82 \\
103 \\
103 \\
99 \\
100 \\
104\end{array}$ & $\begin{array}{l}0.43 \\
0.48 \\
0.41 \\
0.49 \\
0.44 \\
0.40\end{array}$ & $\begin{array}{l}95.2 \\
95.8 \\
\\
97.3 \\
96.5 \\
95.3\end{array}$ & \\
\hline $\begin{array}{c}\text { Ib Eleva } \\
\text { G.A. } \\
\text { D.G. } \\
\text { C.D. } \\
\text { F.B. }\end{array}$ & $\begin{array}{c}\text { natoc } \\
47 \\
73 \\
44 \\
65\end{array}$ & $\begin{array}{l}\mathrm{M} \\
\mathrm{F} \\
\mathrm{M} \\
\mathrm{M}\end{array}$ & $\begin{array}{l}86.5 \\
55.7 \\
70.5 \\
57.5\end{array}$ & $\begin{array}{r}82 \\
116 \\
94 \\
90\end{array}$ & $\begin{array}{l}0.53 \\
0.53 \\
0.53 \\
0.55\end{array}$ & $\begin{array}{l}98.9 \\
96.0 \\
94.2\end{array}$ & $\begin{array}{l}100^{-} \\
100^{+} \\
99.2\end{array}$ \\
\hline
\end{tabular}

direct Fick principle in one patient (S.Tu.) and with indicator dilution curves in the others. Mixed venous blood was sampled from the pulmonary artery and arterial blood from the brachial artery. Oxygen consumption was measured with a $9 \mathrm{~L}$ Collins respirometer while the subjects were breathing 100 per cent oxygen. Oxygen content of blood was determined by the Van SlykeNeill method.

Indicator dilution curves were obtained while the subjects were breathing 100 per cent oxygen from the Collins respirometer. Thirteen to $19 \mathrm{mg}$ of Evans blue dye was rapidly injected from a calibrated syringe into the main pulmonary artery in 3 patients (D.G., G.S. and A.L.) and into an antecubital vein, with prompt elevation of the subject's arm, in the remaining 17 . Using a rotating multiple-sampling device which was adjusted to collect samples at 2 -second intervals, brachial arterial blood was collected through a no. 17-T Cournand needle and a short polyethylene tube, in tubes containing a few particles of powdered heparin. The arterial blood was centrifuged, and the optical density of the undiluted plasma was read twice with a Beckman DU spectrophotometer at $620 \mathrm{~m} \mu$.
Indicator dilution curves were constructed on semilogarithmic paper from the plasma concentration of T-1824. Cardiac output and mean transit time were calculated by mathematically extrapolating the downslope of the dye curve to zero concentration as described by Lilienfield and Kovach (7). Stroke volume was obtained by dividing cardiac output by heart rate. Arterial hematocrits were read in Wintrobe tubes after centrifugation at 2,260 $\mathrm{G}$ for 30 minutes. Red cell volume was measured by the dilution of $\mathrm{Cr}^{\text {s1 }}$-labeled red cells as described previously (8). In calculating plasma volume from the $\mathrm{Cr}^{51}$ cell determinations, the total body hematocrit was assumed to be 0.92 times the large vessel hematocrit $(8,9)$. Direct measurement from T-1824 concentrations after 10 minutes of equilibration gave similar plasma volume measurements. The blood volume data recorded in Table III are those derived from the $\mathrm{Cr}^{51}$ method.

\section{RESULTS}

Data obtained in individual subjects are summarized in Table III. Oxygen consumption ap-

TABLE II

Clinical and laboratory summary of subjects with chronic hypervolemia (polycythemia vera)

\begin{tabular}{|c|c|c|c|c|c|c|c|c|c|c|c|}
\hline \multirow[b]{2}{*}{ Patient } & \multirow[b]{2}{*}{ Age } & \multirow[b]{2}{*}{ Sex } & \multirow[b]{2}{*}{ Weight } & \multirow[b]{2}{*}{$\begin{array}{c}\text { Duration } \\
\text { of } \\
\text { symptoms }\end{array}$} & \multirow[b]{2}{*}{$\begin{array}{c}\text { Previous } \\
\text { treat- } \\
\text { ment }\end{array}$} & \multirow[b]{2}{*}{$\begin{array}{l}\text { Arterial } \\
\text { Hct. }\end{array}$} & \multirow{2}{*}{$\begin{array}{c}\text { Mean } \\
\text { brachial } \\
\text { arterial } \\
\text { pressure }\end{array}$} & \multirow[b]{2}{*}{ WBC } & \multirow[b]{2}{*}{ Platelets } & \multicolumn{2}{|c|}{$\begin{array}{c}\text { Arterial oxygen } \\
\% \text { saturation }\end{array}$} \\
\hline & & & & & & & & & & Air & $\begin{array}{l}100 \% \\
\text { Oxygen }\end{array}$ \\
\hline & yrs & & $k g$ & mos & & $\%$ & $m m H g$ & \multicolumn{2}{|c|}{$10^{3} / \mathrm{cu} \mathrm{mm}$} & & \\
\hline $\begin{array}{l}\text { S.Ta. } \\
\text { G.S. } \\
\text { A.L. } \\
\text { F.Y. } \\
\text { T.S. } \\
\text { H.W. } \\
\text { R.S. } \\
\text { S.Tu. } \\
\text { J.F. } \\
\text { B.P. }\end{array}$ & $\begin{array}{l}76 \\
65 \\
61 \\
42 \\
68 \\
68 \\
55 \\
33 \\
33 \\
65\end{array}$ & $\begin{array}{l}\mathbf{F} \\
\mathbf{F} \\
\mathbf{M} \\
\mathbf{M} \\
\mathbf{M} \\
\mathbf{M} \\
\mathbf{M} \\
\mathbf{F} \\
\mathbf{M} \\
\mathbf{M}\end{array}$ & $\begin{array}{l}45.3 \\
51.4 \\
71.8 \\
67.3 \\
58.0 \\
63.6 \\
69.0 \\
58.0 \\
75.9 \\
66.9\end{array}$ & $\begin{array}{r}1 \\
1 \\
1 \\
1 \\
1 \\
12 \\
12 \\
156 \\
60 \\
84\end{array}$ & $\begin{array}{c}0 \\
0 \\
0 \\
0 \\
0 \\
\mathbf{P}^{22 *} \\
\mathrm{P}^{22 *} \\
* \\
\mathrm{P}^{32 *} \\
\mathrm{P}^{32 *}\end{array}$ & $\begin{array}{l}0.65 \\
0.65 \\
0.56 \\
0.60 \\
0.65 \\
0.59 \\
0.56 \\
0.57 \\
0.64 \\
0.56\end{array}$ & $\begin{array}{r}110 \\
120 \\
120 \\
97 \\
128 \\
99 \\
108 \\
81 \\
100 \\
100\end{array}$ & \begin{tabular}{r|}
10.9 \\
16.8 \\
15.3 \\
22.9 \\
18.0 \\
10.3 \\
13.3 \\
8.4 \\
22.8 \\
10.8
\end{tabular} & $\begin{array}{r}186 \\
850 \\
830 \\
1,315 \\
510 \\
220 \\
330 \\
220 \\
258 \\
184\end{array}$ & $\begin{array}{l}95.0 \\
93.0 \\
94.1 \\
94.0 \\
93.3 \\
93.7 \\
97.0 \\
99.5 \\
96.9 \\
91.6\end{array}$ & $\begin{array}{c}100^{+} \\
99.5 \\
98.7 \\
97.4 \\
100^{+} \\
99.5 \\
100^{+} \\
100^{+} \\
99.0 \\
100^{+}\end{array}$ \\
\hline
\end{tabular}

* One or more phlebotomies. 


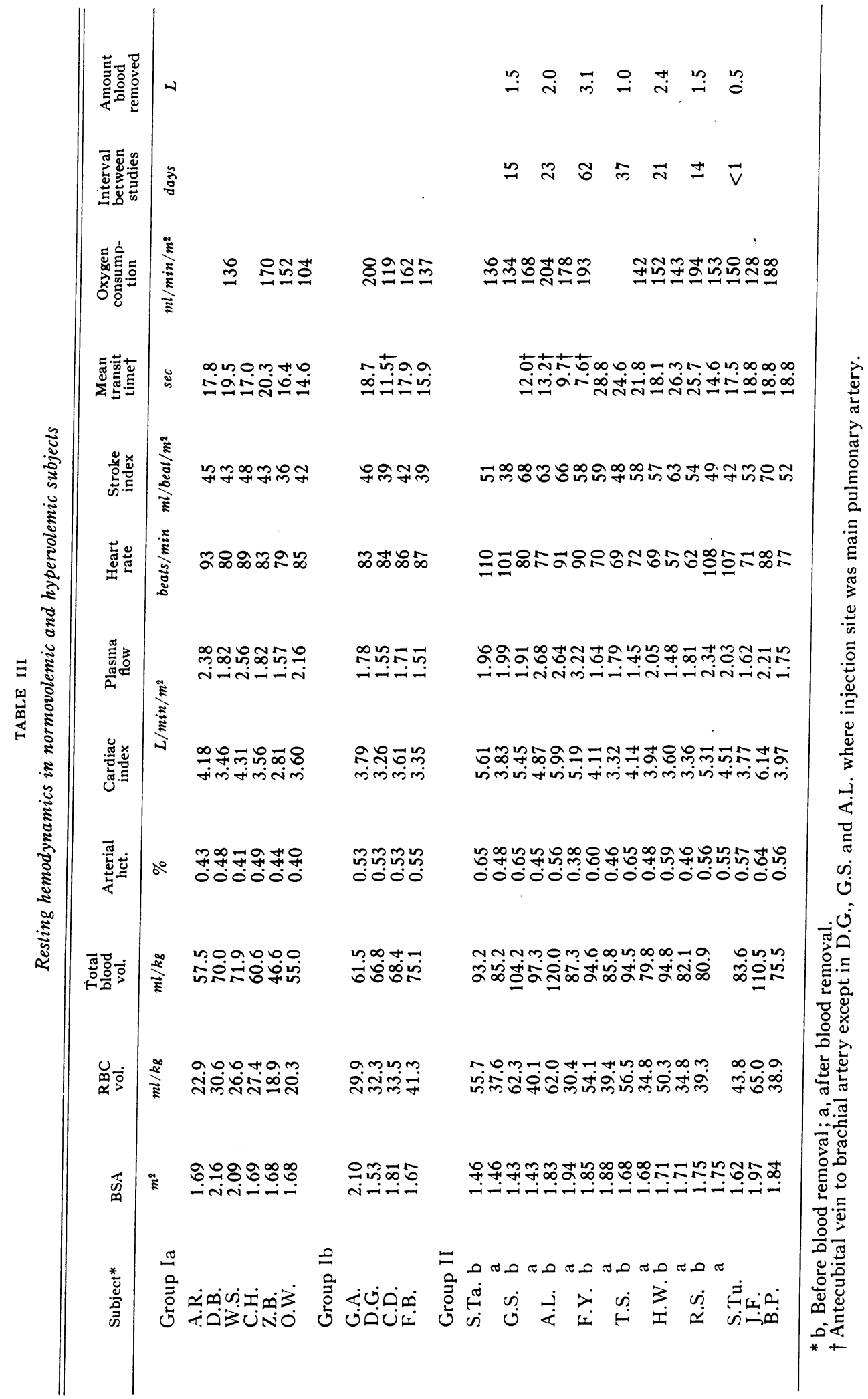


peared to be similar between the subjects in Groups I and II. The average for the former was $148 \mathrm{ml}$ per $\mathrm{m}^{2}$ per minute, and in subjects with polycythemia vera, $155 \mathrm{ml}$ per $\mathrm{m}^{2}$ per minute. The mean arterial oxygen saturations were 96,96 and 95 per cent in Groups Ia, Ib and II. Oxygen content of blood differed; Group Ia had an average arterial oxygen content of 17.83; Group Ib, 20.81; Group II, 22.04 volumes per cent.

The average cardiac output of $3.65 \mathrm{~L}$ per minute per $\mathrm{m}^{2}$ in the normovolemic subjects with normal hematocrit (Group Ia) was similar to that of $3.50 \mathrm{~L}$ per minute per $\mathrm{m}^{2}$ in Group Ib with elevated hematocrits but normal blood volume. In the polycythemia group (II), output was 32 per cent higher, i.e., $4.81 \mathrm{~L}$ per minute per $\mathrm{m}^{2}$. When both arterial oxygen content and cardiac output are considered, the total oxygen available to the tissues per unit of time was greater by 19 per cent in Group Ib and by 70 per cent in Group II, compared with Group Ia.

Blood volume measurements indicated an average red cell mass of $24 \mathrm{ml}$ per $\mathrm{kg}$ in Group Ia, 34 $\mathrm{ml}$ per $\mathrm{kg}$ in Group $\mathrm{Ib}$, and $53 \mathrm{ml}$ per $\mathrm{kg}$ in Group II. Plasma volumes were 36, 34 and 42; total blood volumes were 60,68 and $95 \mathrm{ml}$ per $\mathrm{kg}$. The body hematocrit correction factor ${ }^{1}$ was 0.87 , 0.92 , and 0.91 in Groups Ia, Ib, and II. These similar values would seem to exclude any significant blood vessel distributional difference among the three groups. Five of the 10 hypervolemic patients with polycythemia vera had high cardiac outputs (Figure 1). Comparing those with high and normal output, the former had an average blood volume of $102 \mathrm{ml}$ per $\mathrm{kg}$ versus $89 \mathrm{ml}$ per $\mathrm{kg}$ in the latter. There was no apparent difference between the five subjects with normal output and the five with high output when evaluated from the standpoint of duration of illness, splenomegaly. hematocrit level, oxygen consumption or age. Pulse rate was greater in the subjects with a high output (95 versus 69 beats per minute). There was a high degree of correlation $(R=+0.94)$ between blood volume and resting stroke volume in all subjects studied. The output per beat per $\mathrm{m}^{2}$

\footnotetext{
1 Where mean body hematocrit correction factor $=$ $\frac{\text { red cell volume }\left(\mathrm{Cr}^{31}\right)}{\text { red cell volume }\left(\mathrm{Cr}^{51}\right)+\text { plasma volume } \mathrm{T}-1824} \times$

1 arterial hematocrit
}

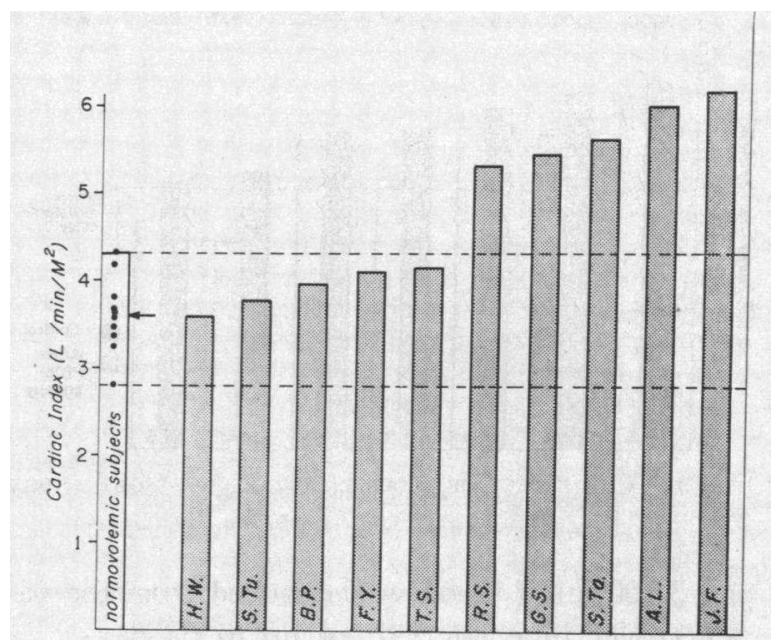

Fig. 1. RESTING CARdiac OUTPUT EXPRESSED AS CARDIAC INDEX IN CONTROLS AND POLYCYTHEMIC SUBJECTS.

exceeded normal values in all of the polycythemia patients, and the correlation coefficient between blood volume and stroke volume corrected for body surface area was +0.91 (Figure 2). Similarly, cardiac index correlated well with blood volume per $m^{2}(R=+0.76)$. The mean transit time (antecubital vein to brachial artery) of $21.1 \mathrm{sec}-$ onds in the hypervolemic patients was slightly greater than the average value of 17.6 seconds in the normovolemic subjects.

These results suggested a relationship between the increased blood volume and elevated stroke output. In order to evaluate this relationship and the significance of the other measurements, seven patients with polycythemia vera were restudied following phlebotomy. Between 500

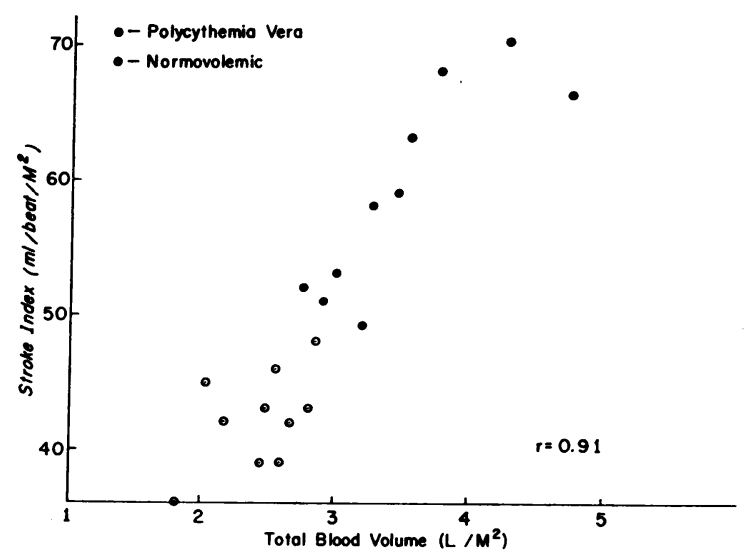

Fig. 2. THE RELATIONSHIP BETWEEN TOTAL BLOOD VOLUME AND RESTING STROKE INDEX IN NORMOVOLEMIC AND POLYCYTHEMIC SURJECTS. 


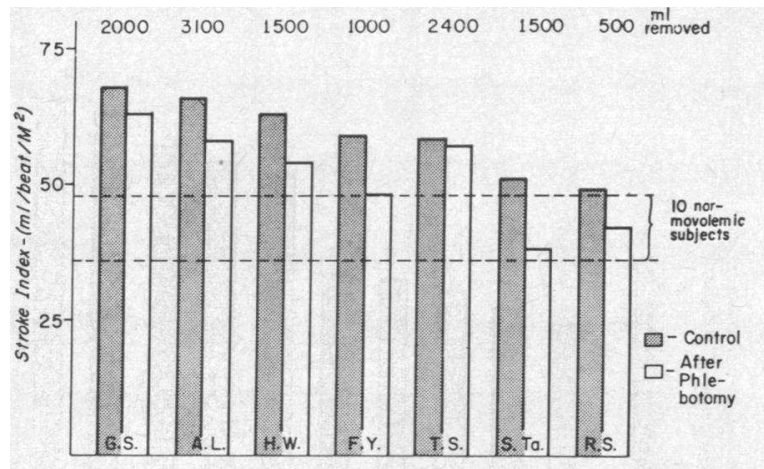

Fig. 3. The efFect of Blood Removal on STROKe index in POLYCYTHEMia Vera.

and $3,100 \mathrm{ml}$ of blood was removed from the patients over time intervals of up to 62 days. In the six subjects studied two to, eight weeks postphlebotomy (excluding the one instance when measurements were made immediately after bleeding), the average hematocrit was reduced from 0.62 to 0.45 . Blood volume fell from 100.2 to $86.3 \mathrm{ml}$ per $\mathrm{kg}$. Cardiac index was reduced from 4.8 to $4.1 \mathrm{~L}$ per minute per $\mathrm{m}^{2}$, and stroke index fell correspondingly from 61 to $53 \mathrm{ml}$ per beat per $\mathrm{m}^{2}$. The decreases, while not of great magnitude, were significant in that they occurred in each patient subjected to phlebotomy (Figure 3).

In the instances of intracardiac pressures measured in polycythemia vera (S.Ta., G.S. and A.L.), mean right atrial pressures were 1,3 and 3 ; mean pulmonary artery, 12, 13 and 25; and pulmonary "capillary," 9, 9 and $11 \mathrm{~mm} \mathrm{Hg}$.

In the patients with polycythemia there was a significant correlation of total blood volume and oxygen consumption per $\mathrm{m}^{2}$; the coefficient of correlation between these parameters prior to phlebotomy was 0.89 ( $\mathrm{p}<0.001)$. Oxygen consumption in the normovolemic subjects, however, showed no such relationship, although there was considerable overlap in oxygen consumption between the two groups. Red cell mass in the polycythemic subjects was similarly related to oxygen uptake.

\section{DISCUSSION}

Previous estimates of cardiac output in polycythemia vera have been limited and have been performed by the indirect Fick principle. Altschule, Volk and Henstell, employing the ethyl iodide method of measurement, reported normal output in three patients (10). Brooks also re- ported a normal cardiac index in one patient (11). Several others have agreed that retardation of peripheral blood flow is a prominent feature of polycythemia vera (12). Goldsmith, estimating output by the acetylene method, reported increased output in one of four patients studied (13). These reports are so limited in number as well as in methods that conclusions can not be drawn.

The present studies show a normal or elevated cardiac output and a consistently increased stroke volume in polycythemia vera. This is opposite to the experimental results obtained by Richardson and Guyton (1) in acutely induced normovolemic polycythemia.

The explanation for the elevated stroke index would appear to relate to the altered blood volume in polycythemia vera. That hypervolemia exerts its effect through increased central blood volume and enhanced diastolic filling seems logical (14). It is possible that the increased cardiac output observed in five of the ten subjects was in part dependent upon increased venous return, similar to the transient effects described with acute hypervolemia in dogs (15). From other studies there is evidence that acute hypervolemia achieved by the infusion of dextran and other blood volume expanders increases output $(2,4,6,16)$. These techniques also produce a decrease in hematocrit as a complicating feature. The present study indicates that high output occurs with hypervolemia even in the presence of an elevated hematocrit. These observations in the chronic hypervolemia of polycythemia vera may be compared with the studies of Kjellberg, Rudhe and Sjöstrand in which an augmentation of blood volume and work capacity per heart beat were observed in trained athletes (17). The possible relationship between increased output observed with high altitude polycythemia (18) and altered blood volume would seem to merit study.

Although blood volume correlated with both stroke volume and cardiac output in this study, the question should be raised whether hypervolemia was a causal factor or whether this correlation was incidental. The fall in cardiac output and stroke volume after blood volume was reduced by phlebotomy suggests that the hyperkinemia does indeed causally relate to chronic hypervolemia or some feature thereof. Recent observations on normal subjects show that acute bleeding results 
in a decreased stroke volume which is correlated with the reduction in "central blood volume" (19). It was of some interest also that the effect of the increased cardiac output was to maintain a normal plasma flow in the patients (Figure 4). Although body tissues may have plasma flow requirements that influence cardiac regulation, such considerations at present remain conjectural.

Under the conditions of this study there is a notable lack of correlation between oxygen requirement, as reflected by oxygen consumption, and oxygen supply, as measured by hemoglobin concentration and cardiac output. In looking further into possible correlations, it is equally apparent that poor correlation exists between oxygen consumption, which presents similar average values in the three groups of subjects, and the blood volume, which is considerably elevated in the polycythemia vera group. There is, however, an impressive correlation between blood volume and oxygen consumption among the individuals of the polycythemia vera group $(\mathrm{R}=+0.89)$. One might suggest that increased blood volume per se could affect cardiac work and perhaps metabolic activity of other tissues. There was some correlation between oxygen consumption and cardiac work $(\mathrm{R}=+0.69)$ and stroke volume $(\mathrm{R}=+$ 0.78 ), but not with heart rate or arterial blood pressure. However, post-phlebotomy studies appear to negate this reasoning, since a reduction in blood volume was associated with no change, or perhaps with a slight increase in oxygen consumption. A second explanation would seem to be the

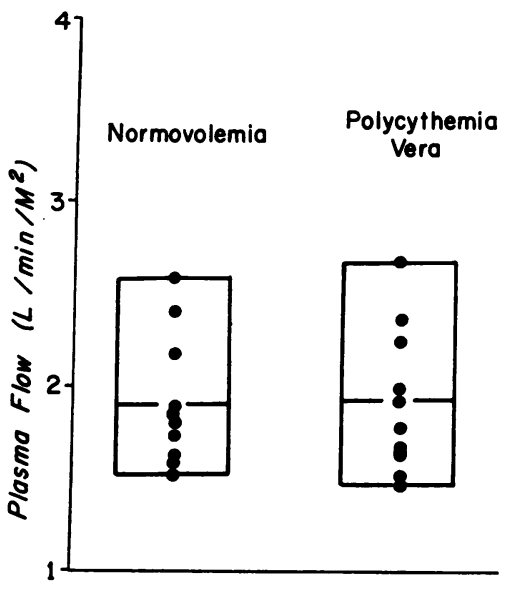

Fig. 4. Plasma flow in NORMovolemic and polyCYTHEMIC SUBJECTS. possible contribution of enhanced hematopoietic activity to the general body metabolic rate. Thus the increased red cell mass or blood volume and the enhanced metabolic activity would both be manifestations of the marrow disturbance. The explanation for this, association awaits further studies, but two additional features might be mentioned : 1) that while Bliss (20) reported a tendency for increased metabolic rate in polycythemia vera, our average oxygen consumption is not above that of the two other groups studied; and 2) while there is a correlation between oxygen consumption and total blood volume or red blood cell mass, there is no correlation between oxygen consumption and hematocrit levels in the polycythemia vera patients.

\section{SUMMARY AND CONCLUSIONS}

Resting hemodynamic studies were performed in 10 patients with expanded blood volumes due to polycythemia vera. In comparison with comparable groups of normovolemic subjects, the patients with polycythemia showed a consistently elevated stroke index (39 per cent) as well as a significant but less uniform increase in cardiac index (34 per cent).

The augmentation of stroke volume described in these patients was closely related to the increase in total blood volume. There was excellent correlation between resting stroke index and total blood volume per $\mathrm{m}^{2}$ in the 20 patients studied $(\mathrm{R}=+0.91)$.

Phlebotomies, performed in seven patients, were followed by a reduction in stroke volume and cardiac output in all instances.

The rate of plasma flow was found to be normal in polycythemia vera.

In patients with polycythemia there was a significant correlation between oxygen consumption and total blood volume.

\section{ACKNOWLEDGMENTS}

The authors are grateful to Doctors Daniel H. Coleman, Quin B. DeMarsh, Harold E. Laws and Alexander R. Stevens, Jr., for affording us the opportunity to study their patients.

\section{REFERENCES}

1. Richardson, T. Q., and Guyton, A. C. Effects of polycythemia and anemia on cardiac output and other circulatory factors. Amer. J. Physiol. 1959, $197,1167$. 
2. Withan, A. C., Fleming, J. W., and Bloom, W. L. The effect of the intravenous administration of dextran on cardiac output and other circulatory dynamics. J. clin. Invest. 1951, 30, 897.

3. Ferguson, T. B., Shadle, O. W., and Gregg, D. E. Effect of blood and saline infusion on ventricular and diastolic pressure, stroke work, stroke volume and cardiac output in the open and closed chest dog. Circulat. Res. 1953, 1, 62.

4. Gowdey, C. W., Hatcher, J. D., and Sunahara, F. A. Cardiovascular responses in dogs to large intravenous infusions. Canad. J. Biochem. 1954, 32, 282.

5. Holt, J. P. Effect of plethora and hemorrhage on left ventricular volume and pressure. Circulat. Res. 1957, 5, 273.

6. Schnabel, T. G., Jr., Eliasch, H., Thomasson, B., and Werkö, L. The effect of experimentally induced hypervolemia on cardiac function in normal subjects and patients with mitral stenosis. J. clin. Invest. 1959, 38, 117.

7. Lilienfield, L. S., and Kovach, R. D. Simplified method for calculating flow, mean circulation time and downslope from indicator-dilution curves. Proc. Soc. exp. Biol. (N. Y.) 1956, 91, 595.

8. Donohue, D. M., Motulsky, A. G., Giblett, E. R., Pirzio-Biroli, G., Viranuvatti, V., and Finch, C. A. The use of chromium as a red-cell tag. Brit. J. Haemat. 1955, 1, 249.

9. Chaplin, H., Jr., Mollison, P. L., and Vetter, H. The body/venous hematocrit ratio: Its constancy over a wide hematocrit range. J. clin. Invest. 1953, 32, 1309.

10. Altschule, M. D., Volk, M. C., and Henstell, H. Cardiac and respiratory function at rest in patients with uncomplicated polycythemia vera. Amer. J. med. Sci. 1940, 200, 478.

11. Brooks, W. D. W. Circulatory adjustments in polycythemia rubra vera. Proc. roy. Soc. Med. 1936, 29, 1379.

12. Lawrence, J. H. Polycythemia. New York, Grune and Stratton, 1955 , p. 8.

13. Goldsmith, G. Cardiac output in polycythaemia vera. Arch. intern. Med. 1936, 58, 1041.

14. Sjöstrand, T. Volume and distribution of blood and their significance in regulating the circulation. Physiol. Rev. 1953, 33, 202.

15. Guyton, A. C., Lindsey, A. IV., Kaufmann, B. N., and Abernathy, J. B. Effect of blood transfusion and hemorrhage on cardiac output and on the venous return curve. Amer. J. Physiol. 1958, 194, 263.

16. Fowler, N. O., Franch, R. H., and Bloom, W. L. Hemodynamic effects of anemia with and without plasma volume expansion. Circulat. Res. 1956, 4, 319.

17. Kjellberg, S. R., Rudhe, U., and Sjöstrand, T. Increase of the amount of hemoglobin and blood vol ume in connection with physical training. Acta physiol. scand. 1949, 19, 146.

18. Theilen, E. O., Gregg, D.' E., and Rotta, A. Exercise and cardiac work response at high altitude. Circulation 1955, 12, 383.

19. Ralston, L. A., Cobb, L. A., and Bruce, R. A. The role of blood volume in regulation of cardiac output, the effects of arterial bleeding in normal subjects. Clin. Res. 1960, 8, 124.

20. Bliss, T. L. Basal metabolism in polycythemia vera. Ann. intern. Med. 1929, 2, 1155. 